\title{
Amílcar Cabral and the Liberation of Guinea-Bissau and Cape Verde: International, Transnational, and Global Dimensions
}

Rui Lopes, Instituto de História Contemporânea, Faculdade de Ciências Sociais e Humanas da Universidade NOVA de Lisboa, ruilopes@fcsh.pt, rmpvl@yahoo.com (corresponding author)

Víctor Barros, Instituto de História Contemporânea, Faculdade de Ciências Sociais e Humanas da Universidade NOVA de Lisboa, vbarros@fcsh.unl.pt, v-barros@hotmail.com

\section{4,417 words}

This themed section explores various international and transnational dimensions of the struggle for the decolonisation of Guinea-Bissau and Cape Verde in the 1960s and early 1970s. Its articles analyse how the path to independence of these relatively small West African nations tied into a wide array of interconnected historical processes taking place around the world, from the streets of Paris to the Great Hall of the People, in Beijing. The aim is to shed new light on the circulation of ideas and foreign connections involved in this struggle, especially those of Amílcar Cabral (1924-73), founding leader of the liberation movement Partido Africano para a Independência da Guiné e Cabo Verde (PAIGC) and widely regarded as a key thinker of African emancipation, alongside Frantz Fanon and Kwame Nkrumah. In particular, this collection of articles examines how the struggle both shaped and was shaped by larger and/or distant trends, including Third World solidarity networks, the spread of the Cold War to Africa, and the impact of tiersmondisme in the northern world. It thus contributes to assess the impact of African politics beyond the African continent, as well as to highlight the role of the international community in African liberation and in the emergence of postcolonial states. In other words, it serves as a gateway through which to look at a key moment of the recent African past as well as a springboard for a wider reflection about the role of extranational dynamics in the formation of national political subjects.

Crucially, the case of Guinea-Bissau and Cape Verde shows how these processes were neither linear nor monolithic, having mobilised different state and non-state players while combining armed combat with an elaborate diplomatic outreach. The history of 
indigenous resistance in so-called 'Portuguese Guinea' spans centuries, with scholars typically observing that, as a result, colonial influence was always limited to certain areas, the Portuguese unable to fully undermine much of the countryside's social foundations of authority. ${ }^{1}$ Between 1963 and 1974, however, resistance reached a whole new level, as this small coastal territory - then awkwardly stuck between Léopold Senghor's proWestern Senegal and Ahmed Sékou Touré's socialist Guinea-Conakry - became the stage of one of the most violent anticolonial conflicts, culminating in a unilateral proclamation of independence, in September 1973, that was recognised by most members of the United Nations. The PAIGC stood out as a movement fighting for the liberation of, not one, but two colonies (i.e. not just Guinea-Bissau, where the war was taking place, but also the nearby Cape Verde archipelago), pursuing both the disintegration of imperial ties and a unitary political project encompassing geographically separate territories. As Colm Foy put it: 'Despite the preoccupations of the world with the Vietnam war, little GuineaBissau and Cape Verde captured the imagination of the international community'. ${ }^{2}$

At the time, Portugal was run by a right-wing dictatorship - 'Estado Novo' - going back to before World War II and firmly integrated in the Western Bloc, most prominently through its NATO membership. Leaders António de Oliveira Salazar (1933-68) and Marcelo Caetano (1968-74) rejected African demands for self-determination, deploying armed forces to fight liberation movements, not just in Guinea-Bissau, but also in the larger colonies of Angola and Mozambique since 1961 and 1964, respectively. These protracted wars ultimately led to the Estado Novo's collapse through the Carnation Revolution, prompted by discontented military officers on 25 April 1974, which in turn led to Portugal's recognition of its colonies' independence. This topic, therefore, ties directly into the broader history of the formal dissolution of European empires in the midto-late twentieth century as well as into the more specific history of Portugal's fascism and late colonialism. The weight of external factors on the latter has been increasingly established, ${ }^{3}$ most notably through studies focusing on different levels of Portuguese interaction with the outside world, including within the colonies themselves ${ }^{4}$ and in international institutions like the $\mathrm{UN}^{5}$ and NATO, ${ }^{6}$ as well as in the Estado Novo's bilateral relations with its western allies. ${ }^{7}$ Yet this history has to be articulated with the story of the liberation movements' own interactions with the outside, including a greater consideration for the diverse ramifications of their struggles.

The liberation struggles entailed the establishment of lasting bilateral ties (which carried over into the independence era) as well as more scattered transnational 
phenomena. They played a prominent role in the Third World's emancipatory demands, ${ }^{8}$ contributed to the boom of militant audiovisual culture across the globe, ${ }^{9}$ and influenced the idiom of European anti-imperialist groups along with the development of anticolonial solidarity networks. ${ }^{10}$ Scholars continue to find new connections and a sense of expanding scale regarding the vast set of foreign material, technical, financial, military, humanitarian, and propagandistic resources African movements were able to mobilise. ${ }^{11}$ While the international connections of Movimento Popular de Libertação de Angola (MPLA) have been amply acknowledged by Cold War studies in light of the postindependence war in Angola, the efforts of Frente de Libertação de Moçambique (FRELIMO) have also received particular attention, ${ }^{12}$ as has the support provided by states in the Soviet Bloc. ${ }^{13}$

In the case of Guinea-Bissau and Cape Verde, the literature - which has covered the PAIGC's recruitment process, ${ }^{14}$ political organisation, ${ }^{15}$ binational project, ${ }^{16}$ military strategy, ${ }^{17}$ state-building ${ }^{18}$, and relations with traditional communities ${ }^{19}$ as well as women's participation in the struggle ${ }^{20}$ - tends to value the importance of international support for the maintenance of the 'liberated areas' and continuation of the war effort, ${ }^{21}$ with some identifying Amílcar Cabral's successful pursuit of goodwill abroad as one of his greatest legacies. ${ }^{22}$ However, biographers often subsume this dimension into a narrow narrative about Cabral's political performance as an outstanding diplomat able to woo foreign leaders and supporters. ${ }^{23}$ Other authors prefer to discuss his contribution beyond the strict field of the history of Guinean and Cape Verdean national liberation. ${ }^{24}$ Yet the PAIGC's international alignments deserve closer observation, both because only through a plural and critical analysis of its struggle can we grasp the challenges of the independent states that followed ${ }^{25}$ and because, as this dossier demonstrates, they can illuminate new angles of global narratives, expanding the themes, debates, directions, and sources of this period's historiography.

This themed section emerges in the context of the research project Amílcar Cabral: from Political History to the Politics of Memory, which studies Cabral's evolution as a political actor with global projection. In the five original articles selected for the dossier, some of the project's researchers and an invited collaborator delve into disparate areas of Cabral's network of contacts, which ranged from secret ties to Eastern European state organisations (as evidenced by Natalia Telepneva's ground-breaking research) to exchanges with sections of Western civil society (as mapped out by Víctor Barros' article) in addition to public interventions across the Third World (as discussed 
by Branwen Gruffydd Jones). Yet the articles also seek to expand the focus beyond the figure of Cabral, further examining the wider context that framed the liberation struggle. Drawing on different types of written, filmed, and oral sources and archives from Africa, America, and Europe, they zoom in on a range of foreign actors who crucially interacted with the PAIGC's representatives and ideas, having simultaneously collaborated in the forging of Guinea-Bissau's and Cape Verde's national identity and in the internationalisation of those countries' path to independence. Through this gesture, the dossier contributes to situate the movement's struggle in the circulation of anticolonial thought and practice around the world, touching upon three broader dynamics we would like to highlight in this introduction.

Firstly, the struggle is inserted into the evolving conversations over competing conceptions of African identity and strategies of liberation in the decolonising world. For all their emphasis on cooperation, Pan-African, Non-Aligned, and Third World fora were sites of critical, passionate discussion. There, Amílcar Cabral forged alliances and promoted his vision, most notably - as discussed throughout the dossier - at 1966's Tricontinental Conference of African, Asian, and Latin American Peoples, in Havana, where he uttered his famous address 'The Weapon of Theory'. Branwen Gruffydd Jones' article, in particular, explores Cabral's and his fellow militants' contribution to shift African debates from a Senghorian focus on race and elite culture to Fanonian links between class, colonialism, and liberation. Yet divisions were not felt just at a continental level, but also within the struggle itself, including tensions inside the PAIGC (between Guineans and Cape Verdeans as well as between Guinea's different ethnic groups) and between the PAIGC and smaller liberation movements like the Frente de Luta pela Independência Nacional da Guiné (FLING). Although for the most part Cabral's international partners ignored these tensions, Julião Soares Sousa's article explains how the FLING may have temporarily benefitted from Chinese aid in retaliation for, among other things, the PAIGC's criticism of China's tolerance for Portuguese colonialism in Macao. The dossier thus underscores that the story of decolonisation was not just one of dispute between the subaltern South and the imperial North (or, as discussed below, between the allies of East and West), but also one of clashes between different 'southern' voices.

Secondly, the liberation of Guinea-Bissau and Cape Verde is framed in the context of what Odd Arne Westad labelled the 'Global Cold War'. ${ }^{26}$ Westad's effort to decentre the lens of Cold War studies by shifting their focus towards the Third World aligned with 
Tony Smith's own proposal for a 'pericentric' approach to that conflict, arguing that the Cold War was not just 'pushed' by the centre onto the periphery; the superpowers were also 'pulled' by outside actors who fed on and contributed to the East-West rivalry in order to pursue local agendas driven by nationalism, personal ambitions, and ideological commitment to capitalist or socialist versions of high modernism. ${ }^{27}$ Many of the articles in this dossier contribute to such a decentred, pericentric understanding of the Cold War by showing how seemingly 'peripheral' actors like the Czechoslovak secret services, the Communist Party of China, and Cuban filmmakers autonomously embraced the antiimperialist dimension of the war in Guinea-Bissau. Addressing those - so far, practically unresearched - ties is not to reduce the liberation struggle to a mere proxy conflict, with communist-backed 'pawns' pitted against the US-backed Portugal. Rather, each article acknowledges Amílcar Cabral's active role in the process: Natalia Telepneva argues that he shaped his relationship with Czechoslovakia's intelligence to his movement's advantage, Julião Soares Sousa highlights Cabral's refusal to cave in to Chinese pressure to take a side in the Sino-Soviet split, Catarina Laranjeiro concludes that he effectively used Cuban cinema to stage his image and his vision of liberation. Without seeking to dilute the concept of Cold War beyond intelligibility through its loose fusion with the history of decolonisation, ${ }^{28}$ the articles help further establish that these two phenomena were profoundly interconnected, even if none of them should be seen as a sufficient explanation for the other (i.e. the Cold War was not the trigger for decolonisation, just as the latter did not originate the former). This connection, in turn, can be subsumed into the larger history of the rise of the twentieth-century nation-state, as formal decolonisation led to the emergence of new nation-states against the background of a world order of Cold War-prompted international institutions designed to regulate interstate relations. ${ }^{29}$

Thirdly, the liberation struggle is presented within the framework of the relations between the Global South and Western Europe. Like the Cold War and nationalism, decolonisation is often misleadingly presented as a Eurocentric concept that uncritically found its way to the South. As Martin Shipway points out, studies in this field tend to privilege the story of the breakdown of imperial systems and of the associated structural shifts in the international order over the various colonies' individual narratives, attributing much of the dynamism and initiative behind decolonisation to the former empires, thus replicating those empires' own top-down worldview. ${ }^{30}$ The dossier seeks to counter this tendency, starting with its emphasis on African agency, not only on the ground, but also in the very act of promoting the Guinean and Cape Verdean struggle into an 
internationalist cause, which constitutes a clear case of political ideas travelling northwards. Víctor Barros' article, in particular, demonstrates that the PAIGC's cause and rhetoric resonated in France, where they were disseminated by both informal networks and highly organised support committees (comités de soutien) in the form of a plethora of events, publications, and films. These solidarity groups did not merely reproduce those ideas - they adapted and incorporated them into their own political reality, articulating them with their critique of the French government, of the US intervention in Vietnam, and of the capitalist system. This process ultimately mirrors the liberation movements' own appropriation of 'northern' ideas and rhetoric (from the notion of statehood to developmentalism) for their own fight against oppression. It shows transnationality not only as multidirectional, but also as marked by hybridity and productive recontextualization. In turn, Catarina Laranjeiro shows how the PAIGC's global connections produced complex triangulations such as the diplomatic incident brought about by the Portuguese authorities' capture of a Cuban soldier fighting in Guinea-Bissau.

By stressing these broader dynamics, we seek distance from simplistic 'Great Man' narratives that present the PAIGC's victory as essentially a by-product of Amílcar Cabral's exceptional charisma, a tendency that is all the more problematic because it is contrary to Cabral's own method of political analysis, with its profound emphasis on the contextual and relational dimensions of ideas, consciousness, and practice. The articles in this dossier draw attention to the collaborative dimension of Cabral's work and contextualise his supporters' motivations, placing his actions at the vortex of several historical forces in an increasingly interconnected world. By showing how this struggle brought agents from different countries together and ushered the transnational flow of ideas, weapons, money, books, radio broadcasts, food, uniforms, tobacco, blood, medication, and cinema, the articles validate Martin Thomas' and Andrew S. Thompson's argument that decolonisation was an actively globalising force. ${ }^{31}$ In particular, they demonstrate how the Guinean and Cape-Verdean quest for independence, despite being rooted in a nationalist imagination, involved a conscious interaction with other imaginaries, from a Pan-African rejection of negritude to the Czechoslovak governments' search for prestige within the Warsaw Pact, from Chinese competition with the Soviet Union for influence in the Third World to France's post-May 1968 New Left activism or Cuba's efforts to internationalise its revolution. Taken as a whole, this collection thus helps historicise the - at times smooth, at times turbulent - convergence between Cabral's 
aims and those of various players around the world who, like him, discerned in GuineaBissau's and Cape Verde's liberation struggle a piece of a much larger historical process.

\title{
Notes
}

\begin{abstract}
${ }^{1}$ Armando Tavares da Silva, A Presença Portuguesa na Guiné: História Política e Militar 1878-1926 (Porto: Caminhos Romanos, 2016); Joshua Forrest, 'Guinea-Bissau', in Patrick Chabal (ed), A History of Postcolonial Lusophone Africa (London: Hurst \& Company, 2002), 262; Peter Karibe Mendy, Colonialismo Português em África: A Tradição de Resistência na Guiné-Bissau, 1879-1959 (Bissau: Instituto Nacional de Estudos e Pesquisa/Lisbon: Imprensa Nacional Cada da Moeda, 1994); Carlos Cardoso, 'A Ideologia e a Prática da Colonização Portuguesa na Guiné e o seu Impacto na Estrutura Social, 1926-1973', Soronda. Revista de Estudos Guineenses, 19 (July 1992), 29-63.

${ }^{2}$ Colm Foy, Cape Verde: Politics, Economics and Society (London/New York, NY: Pinter Publishers, 1988), 23.

${ }^{3}$ Valentim Alexandre, Contra o Vento: Portugal, o Império e a Maré Anticolonial (1945-1960) (Lisbon: Temas e Debates, 2017); Pedro Aires Oliveira, 'A descolonização portuguesa: o puzzle internacional', in Fernando Rosas, Mário Machaqueiro and Pedro Aires Oliveira (org), O Adeus ao Império: 40 Anos da Descolonização Portuguesa (Lisbon: Vega, 2017), 60-77; Luís Nuno Rodrigues, 'The International Dimensions of Portuguese Colonial Crisis', in Miguel Bandeira Jerónimo and António Costa Pinto (ed), The Ends of European Colonial Empires: Cases and Comparisons (Cambridge: Palgrave Mcmillan, 2015), 243-267; Norrie MacQueen, The Decolonization of Portuguese Africa: Metropolitican Revolution and the Dissolution of Empire (London: Longman, 1997).

${ }^{4}$ Michel Cahen, 'Anticolonialism \& Nationalism: Deconstructing Synonymy, Investigating Historical Processes. Notes on the Heterogeneity of Former African Colonial Portuguese Areas', in Eric MorierGenoud (ed), Sure Road? Nationalisms in Angola, Guinea-Bissau and Mozambique (Leiden and Boston: Brill, 2012,), 1-30; Patrick Chabal, 'Emergencies and Nationalist Wars in Portuguese Africa', in Robert F. Holland (org), Emergencies and Disorder in the European Empires after 1945 (London: Frank Cass, 1994), 235-249.
\end{abstract}

${ }^{5}$ Aurora Almada e Santos, A Organização das Nações Unidas e a Questão Colonial Portuguesa: 19601974 (Lisbon: Instituto de Defesa Nacional, 2017); Bruno Cardoso Reis, 'Portugal and the UN: A Rogue State Resisting the Norm of Decolonization (1956-1974)', Portuguese Studies, 29:2 (2013), 251-76; António E. Duarte Silva, 'O litígio entre Portugal e a ONU (1960-1974)', Análise Social, 30:130 (1995), 5-50.

${ }^{6}$ Rui Lopes, 'Accommodating and Confronting the Portuguese Dictatorship within NATO, 1970-74', The International History Review, 38:3 (2015), 505-526.

${ }^{7}$ Rui Lopes, West Germany and the Portuguese Dictatorship 1968-1974. Between Cold Ward and Colonialism (Basingstoke: Palgrave McMillan, 2014); Maria José Tíscar, O Pacto Ibérico, a NATO e a Guerra Colonial (Lisbon: Instituto Nacional Casa da Moeda, Instituto da Defesa Nacional, 2014); Ana Mónica Fonseca and Daniel Marcos, 'Cold War Constraints: France, West Germany and Portuguese Decolonization', Portuguese Studies, 29:2 (2013), 209-26; Amaral da Silva Lala, L'Enjeux Colonial dans les Relations Franco-Portugaises 1944-1974 (Ph.D. dissertation, Institut d'Etudes Politiques de Paris, 2007); Pedro Aires Oliveira, Os Despojos da Aliança. A Grã-Bretanha e a Questão Colonial Portuguesa 1945-1975 (Lisbon: Tinta-da-China, 2007); Witney Wright Schneidman, Engaging Africa: Washington and the Fall of Portugal's Colonial Empire (Lanham, Maryland: University Press of America, 2004).

${ }^{8}$ Aurora Almada Santos, 'The Role of the Decolonization Committee of the United Nations Organization in the Struggle against Portuguese Colonialism in Africa: 1961-1974', The Journal of Pan African Studies, 4:10 (2012)

${ }^{9}$ Kodwo Eshun and Ros Gray, 'The Militant Image: A Ciné-Geography', Third Text 25:1 (2011)

${ }^{10}$ Christoph Kalter, The Discovery of the Third World. Decolonization and the Rise of the New Left in France, c.1950-1976 (Cambridge: Cambridge University Press, 2016); Robert Gildea, James Mark \& Niek Pas, 'European Radicals and the 'Third World'. Imagined Solidarities and Radical Networks, 1958-1973', Cultural and Social History, 8:4 (2011), 449-471.

${ }^{11}$ J. Alexander and J. McGregor, B-M. Tendi, 'The Transnational Histories of Southern African Liberation Movements: An Introduction', Journal of Southern African Studies, 43:1 (2017), 1-12; Kim Christiaens, 'Europe at the crossroads of three worlds: alternative histories and connections of European solidarity with 
the Third World, 1950s-80s', European Review of History: Revue Européenne d'Histoire, 24:6 (2017), 932-954; Samantha Christiansen and Zachary A. Scarlett (ed), The Third World in the Global 1960s (New York/Oxford: Berghahn Books, 2013); Hilary Sapire and Chris Saunders (eds), Southern African Struggles. New Local, Regional and Global Perspectives (Cape Town: Cape Town University Press 2013).

${ }^{12}$ Corrado Tornimbeni, 'Nationalism and Internationalism in the Liberation Struggle in Mozambique: The Role of the FRELIMO's Solidarity Network in Italy', South African Historical Journal, 70:1 (2018), 194214; Daniel Kaiser, “Makers of the Bonds and Ties': Transnational Socialisation and National Liberation in Mozambique', Journal of Southern African Studies, 43:1 (2017), 29-48; Natalia Telepneva, 'Mediators of Liberation: Eastern-Bloc Officials, Mozambican Diplomacy and the Origins of Soviet Support for Frelimo, 1958-1965', Journal of Southern African Studies, 43:1 (2017), 67-81.

${ }^{13}$ Lena Dallywater, Chris Saunders, Helder Adegar Fonseca (eds), Southern African Liberation Movements and the Global Cold War "East": Transnational Activism 1960-1990 (Berlin: Walter de Gruyter GmbH, 2019).

14 Ângela Benoliel Coutinho, Os Dirigentes do PAIGC. Da Fundação à Rutura 1956-1980 (Coimbra: Imprensa da Universidade de Coimbra, 2017); Christoph Kohl, 'Ethnicity as Trope of Political Belonging and Conflict: Cape Verdean Identity and Agency in Guinea-Bissau', in Christian K. Højbjerg, Jacqueline Knörr \& William P. Murphy (ed), Politics and Policies in Upper Guinea Coast Societies. Change and Continuity (New York, NY: Palgrave Macmillan, 2017), 223-245; José Vicente Lopes, Cabo Verde, Os Bastidores da Independência (Praia: Spleen Edições, 2002); Dalila Cabrita Mateus, A Luta Pela Independência: A Formação das Elites Fundadoras da FRELIMO, MPLA e PAIGC (Mem Martins: Inquérito, 1999).

15 António E. Duarte Silva, A Independência da Guiné-Bissau e a Descolonização Portuguesa (Porto: Afrontamento, 1997); Jock McCulloch, In the Twilight of Revolution: The Political Theory of Amilcar Cabral (London: Routledge \& Kegan Paul, 1983); Patrick Chabal, Amílcar Cabral: Revolutionary Leadership and People's War (Cambridge: Cambridge University Press, 1983); Lars Rudebeck, GuineaBissau: A Study of Political Mobilization (Uppsala: Scandinavian Institute of African Studies, 1974).

16 José Augusto Pereira, O PAIGC Perante o Dilema Cabo-Verdiano [1959-1974] (Lisbon: Campo da Comunicação, 2015).

17 Julião Soares Sousa, 'Guiledje no Horizonte Político e Militar de Amílcar Cabral. "Guerra de Fronteira" ou uma Projetada "Ofensiva Final”, in José Luís Lima Garcia, Julião Soares Sousa and Sérgio Neto (eds), A Guerra e as Guerras Coloniais na África Subsaariana (Coimbra: Imprensa da Universidade de Coimbra, 2019), 191-219; Mário Beja Santos, História(s) da Guiné-Portuguesa: Da Primeira Colónia do Mundo Moderno até ao País Fundado por Amílcar Cabral (V. N. Famalicão: Edições Húmus, 2015); Leopoldo Amado, Guerra Colonial \& Guerra de Libertação Nacional 1950-1974 (Lisbon: IPAD, 2011).

${ }^{18}$ Francisco Henriques da Silva, Mário Beja Santos, Da Guiné Portuguesa à Guiné-Bissau: Um Roteiro (Porto: Fronteira do Caos Editores, 2014); António E. Duarte Silva, Invenção e Construção da GuinéBissau. Administração Colonial/Nacionalismo/Constitucionalismo (Coimbra: Almedina, 2010); Lars Rudebeck, Conditions of People's Development in Post-Colonial Africa (Uppsala: AKUT, 1990); Carlos Lopes, Guinea-Bissau. From Liberation Struggle to Independent Statehood (Boulder Co: Westview Press, 1987); Rosemary E. Galli and Jocelyn Jones, Guinea-Bissau: Politics, Economics and Society (London: France Pinter, 1987); Judson M. Lyon, 'Marxism and ethno-nationalism in Guinea-Bissau, 1956-76', Ethnic and Racial Studies, 3:2 (1980) , 156-168; Carlos Lopes, Etnia, Estado e Relações de Poder na Guiné-Bissau (Lisbon: Edições 70, 1982); Paulette Pierson-Mathy, La naissance de l'État par la guerre de libération nationale: le cas de la Guinée-Bissau (Paris: UNESCO, 1980); Peter Aaby, The State of GuineaBissau: African Socialism or Socialism in Africa? (Uppsala: Scandinavian Institute of African Studies, 1978); Jean-Claude Andreini \& Marie-Claude Lambert, La Guinée-Bissau: d'Amílcar Cabral à la reconstruction nationale (Paris: L'Harmattan, 1978).

${ }^{19}$ Marina Padrão Temudo, 'From the Margins of the State to the Presidential Palace: The Balanta Case in Guinea-Bissau', African Studies Review, 52:2 (2009), 47-67; Maria da Conceição das Neves Silva, 'Lógicas Pessoais \& Estado Burocratizado Alargado: Dinâmicas de Transição na Guiné-Bissau', in Óscar Soares Barata and Sónia Infante Girão Frias Piepoli (eds), Populações, Ambiente e Desenvolvimento em África (Lisbon: ISCSP, 2001), 309-23; Clara Carvalho, Ritos de Poder e a Recriação da Tradição. Os régulos manjaco da Guiné-Bissau (Ph.D. dissertation, ISCTE Lisbon, 1998); Mamadú Jao, 'Os Poderes Tradicionais no Período de Transição’, in Fafali Koudawo \& Peter Karibe Mendy (eds), Pluralismo Político na Guiné-Bissau: Uma Transição em Curso (Bissau: INEP, 1996), 123-33; Wilson Trajano Filho, 'Invisíveis e Liminares': A Sociedade Crioula e seus Heróis', Soronda. Revista de Estudos Guineenses, 18 (1993), 77-114; Raúl Mendes Fernandes, 'Partido Único e Poderes Tradicionais', Soronda. Revista de Estudos Guineenses, 16 (1993), 39-50. 
${ }^{20}$ Inês Galvão and Catarina Laranjeiro, 'Gender Struggle in Guinea-Bissau: Women's Participation On and Off the Liberation Record', in Nuno Domingos, Miguel B. Jerónimo and Ricardo Roque (eds), Resistance and Colonialism: Insurgent Peoples in World History (Basingstoke: Palgrave Macmillan, 2019), 85-122.

${ }^{21}$ Sónia Vaz Borges, Militant Education, Liberation Struggle, Consciousness: The PAIGC Education in Guinea Bissau 1963-1974 (Berlin: Peter Lang, 2019); David Fistein, 'The Diplomatic Achievements of Amilcar Cabral: A Case Study of Effective Leadership in a Small African State', in Baba G. Jallow (ed), Leadership in Colonial Africa. Disruption of Traditional Frameworks and Patterns (New York, NY: Palgrave Macmillan, 2014), 69-100; Mustafah Dhada, 'Guinea-Bissau's Diplomacy and Liberation Struggle', Portuguese Studies Review, 4:1 (1995), 20-39; Mustafah Dhada, Warriors at Work: How Guinea Was Really Set Free (Colorado: University Press of Colorado, 1993).

${ }^{22}$ Malyn Newitt, 'Os Partidos Nacionalistas no Tempo da Revolução', in Rosas, Machaqueiro, Oliveira, $O$ Adeus ao Império, 25-43; Carlos Lopes, 'Etnia, Estado e Relações', 117.

${ }^{23}$ Peter Karibe Mendy, Amílcar Cabral: A Nationalist and Pan-Africanist Revolutionary (Athens: Ohio, Ohio University Press, 2019); Julião Soares Sousa, Amílcar Cabral (1924-1973). Vida e Morte de um Revolucionário Africano (Coimbra: Edição de Autor, 2016); Daniel dos Santos, Amílcar Cabral: Um Outro Olhar (Lisbon: Chiado Editora, 2014); António Tomás, O Fazedor de Utopias: Uma Biografia de Amílcar Cabral (Lisbon: Tinta-da-China, 2008); José Pedro Castanheira, Qui a fait tuer Amílcar Cabral? (Paris: L'Harmattan, 2003); Patrick Chabal, Amilcar Cabral: Revolutionary Leadership and People's War (Cambridge: Cambridge University Press, 1983); Mário de Andrade, Amílcar Cabral. Essai de Biographie Politique (Paris: François Maspero, 1980).

${ }^{24}$ Filipa César, 'Meteorisations: Reading Amílcar Cabral's Agronomy of Liberation', Third Text, 32:2-3 (2018), 254-272; José Neves, 'Ideology, science, and people in Amílcar Cabral', História, Ciências, Saúde - Manguinhos, 24:2 (2017), 333-347; P. Khalil Saucier (ed), A Luta Continua: (Re)Introducing Amílcar Cabral to a New Generation of Thinkers (Trenton: African World Press, 2017); António Tomás, 'Cabral and the Postcolony: Postcolonial Readings of Revolutionary Hopes', Postcolonial Studies, 19:1 (2016), 2236; Firoze Manji \& Bill Fletcher Jr. (eds.), Claim no Easy Victories: The Legacy of Amílcar Cabral (Codesria and Daraja Press, 2013); Patrícia Villen, Amílcar Cabral e a Crítica do Colonialismo (São Paulo: Expressão Popular, 2013); Carlos Lopes (ed), Africa's Contemporary Challenges: The Legacy of Amílcar Cabral (London: Routledge, 2009); Reiland Rabaka, Africana Critical Theory: Reconstructing the Black Radical Tradition, from W.E.B. Du Bois and C.L.R. James to Frantz Fanon and Amílcar Cabral (New York, NY: Lexington Books, 2009); Charles F. Peterson, Du Bois, Fanon, Cabral: The Margins of Elite Anti-Colonial Leadership (Plymouth: Lexington Books, 2007); Peter Karibe Mendy, 'Amilcar Cabral and the Liberation of Guinea-Bissau: context, challenges and lessons for effective African Leadership', African Identities, 4:1 (2006), 7-21.

${ }^{25}$ As argued in David Fistein, Social Revolutions in Small States. A Comparative Study of Bavaria, Cuba, Guinea-Bissau, Haiti, and Hungary (Germany: VDM Verlag Dr. Mueller, 2010).

${ }^{26}$ Odd Arne Westad, The Global Cold War: Third World Interventions and the Making of Our Times (Cambridge: Cambridge University Press, 2005).

${ }^{27}$ Tony Smith, 'New Bottles for New Wine: A Pericentric Framework for the Study of the Cold War', Diplomatic History, 24:4 (2000), 567-91. The decisive role played by agents beyond the superpowers is further explored in Leslie James and Elisabeth Leake (eds), Decolonization and the Cold War: Negotiating Independence (London: Bloomsbury, 2015).

${ }^{28}$ Thus heeding the advice of Federico Romero, 'Cold War historiography at the crossroads', Cold War History, 14:4 (2014), 685-703.

${ }^{29}$ Ryan M. Irwin, 'Decolonization and the Cold War', in Artemy M. Kalinovsky and Craig Daigle (eds), The Routledge Handbook of the Cold War (New York, NY: Routledge, 2014), 91-104.

${ }^{30}$ Martin Shipway, Decolonization and its Impact. A Comparative Approach to the End of the Colonial Empires (Oxford: Blackwell, 2008), 2-3. For a critique of this tendency applied to the history of GuineaBissau and Cape Verde, see António Tomás, 'Introduction: decolonising the "undecolonisable"? Portugal and the Independence of Lusophone Africa', Social Dynamics 42:1 (2016).

${ }^{31}$ Martin Thomas and Andrew S. Thompson, 'Rethinking Decolonization: A New Research Agenda for the Twenty-First Century' in Martin Thomas and Andrew S. Thompson (eds), The Oxford Handbook of the Ends of Empire (New York: Oxford University Press 2018), 4-5. 